7. Reprod. Fert. (1973) 34, 433-444

\title{
THE PROTEINS IN FLUIDS FROM THE SEMINIFEROUS TUBULES AND RETE TESTIS OF THE RAT
}

\author{
AARNE I. KOSKIMIES AND MARTTI KORMANO \\ Department of Anatomy, University of Helsinki, Finland
}

(Received 31st fuly 1972)

\begin{abstract}
Summary. Proteins in fluids from the seminiferous tubules and rete testis of rats were studied with a high resolution electrophoretic technique, utilizing a step gradient, polyacrylamide gel system. Both fluids contained a number of specific bands, i.e. proteins not seen in serum or in intratesticular lymph. The rete testis fluid contained more serum proteins than the seminiferous tubule fluid. The albumin-globulin ratio was also greater in the former fluid. Two-dimensional separations showed that the bulk of specific proteins moved as prealbumins. Strong esterase and acid phosphatase activities were located in the region of the specific proteins with the intermediate mobility in acrylamide gel. The origin of these proteins and their significance is discussed in relation to the functional differences between the seminiferous tubules and the rete testis.
\end{abstract}

\section{INTRODUCTION}

Both the seminiferous tubules and the rete testis secrete fluid, which bears some resemblance to that of cerebrospinal fluid and aqueous humour in its protein and ionic composition (Setchell, 1970). It has recently been shown that the composition of the fluid within the seminiferous tubules is very stable due to the existence of a blood-testis barrier which regulates the entry of various endogenous and administered substances (Setchell, 1967, 1969).

Our knowledge of the secretory phenomena within the seminiferous epithelium is based mainly on rete testis fluid obtained by a catheter implantation technique (Voglmayr, Waites \& Setchell, 1966), but recently it has been found that the composition of rete testis fluid differs from that of fluid in the seminiferous tubules (Tuck, Setchell, Waites \& Young, 1970; Levine \& Marsh, 1971; Kormano, Koskimies \& Hunter, 1971; Koskimies, Kormano \& Lahti, 1971).

The concentration of protein in rete testis fluid is very much less than in serum or testicular lymph (Johnson \& Setchell, 1968), and there is evidence that the protein concentration of the seminiferous tubule fluid is even lower than that of rete testis fluid (Kormano et al., 1971). All the individual serum proteins seem to be present in rete testis fluid, but the ratio of the concentration to that of serum is greater for albumin than for the larger proteins, with the exception of 
$\alpha_{2}$-macroglobulin (Setchell, 1970). Immunoglobulins are present in very low concentrations in rete testis fluid and, in tubular fluid, the content seems to be negligible (Koskimies et al., 1971).

Johnson \& Setchell (1968) found a specific protein in ram rete testis fluid. This protein migrated between $\alpha_{1}$ - and $\alpha_{2}$-globulin on cellulose acetate electrophoresis. The existence of a protein with a molecular weight less than that of albumin (Setchell, 1967) has also been reported.

The enzyme activity of rete testis fluid has been studied recently by Suominen \& Setchell (1972) but it is not known whether seminiferous tubule fluid differs from the rete testis fluid in this respect. On the basis of the results of chemical and histochemical studies, testicular tissue is known to be rich in non-specific esterase activity (Huggins \& Moulton, 1948) which is mainly distributed in the interstitial cells (Nachlas \& Seligman, 1949). Esterase activity is also found in the seminiferous tubules and is located in the Sertoli cells (Niemi \& Kormano, 1965a). The reaction of these cells is strongest when the maturing spermatids are embedded in the seminiferous epithelium. The cyclical changes have also been shown for acid phosphatase activity in the Sertoli cells (Niemi \& Kormano, 1965b; Pósalaky, Szabó, Bácsi \& Ökörös, 1968) Assuming that Sertoli cells contribute to the secretion of testicular fluid, it might be expected that the respective enzyme activities would be detected in the fluid.

\section{MATERIALS AND METHODS}

\section{Collection of fluids}

Adult Sprague-Dawley rats were used. For the collection of rete testis fluid and for micropunctures, the animals were anaesthetized with Nembutal ${ }^{\star}$ (sodium pentobarbitone), given intraperitoneally.

Rete testis fluid. The rete testis fluid ( 15 to $30 \mu$ from each animal) was collected by puncturing the dilated rete testis $24 \mathrm{hr}$ after ligation of the efferent ducts under ether anaesthesia. The samples were centrifuged (at 15,000 $\mathrm{g}$ for 15 $\mathrm{min}$ ) in order to remove spermatozoa. The same fluid was used for electrophoresis and protein assays.

Seminiferous tubule fluid. Samples of free-flow secretion of the seminiferous tubules were obtained from eight animals by micropuncture. A small incision was made in the tunica albuginea so that some tubules were exposed. One of the protruding seminiferous tubules was subjected to micropuncture with a glass capillary, the outer diameter of the tip of which was 20 to $30 \mu \mathrm{m}$. A small drop of paraffin oil stained with Sudan black was injected into the tubule lumen to check the position of the tip before aspiration of the fluid. Two to four samples of tubular fluid, each of 0.2 to $0.5 \mu$ l, taken from the same testis, were pooled to make one sample for electrophoretic analysis. Tubular fluid was also collected from the testis after efferent duct ligation. The volume of samples from the distended tubules was twice that taken from normal seminiferous tubules. Noncentrifuged samples and samples centrifuged in a glass capillary were compared in some cases. Since no difference was found, further centrifugation of tubular fluid was omitted.

Intratesticular lymph. Testicular lymph was collected through an incision in the 
tunica albuginea by placing a glass capillary between intact seminiferous tubules. Samples of rat serum and plasma were also collected for reference fluids.

\section{Electrophoresis}

Testicular fluid samples were studied with the Ortec high resolution electrophoresis unit, using a step gradient, flat bed, acrylamide gel system (Ortec, 1970). The gel cells used in this system were constructed according to Eränkö's 'sandwich' technique (Eränkö, Hunter \& Koskimies, 1973). The cells were set up for casting and after electrophoresis, they could be taken to pieces and the gel slabs could be removed with ease for further procedures to be carried out.

The electrophoresis utilizes a $0.75 \mathrm{~m}$-tris-sulphate separating gel buffer, $\mathrm{pH}$ 9.0 , with an initial acrylamide concentration of $4.5 \%$, increasing in steps to $6 \%$, $8 \%$ and $12 \%$. Both buffer tanks were filled with 0.065 m-tris-borate buffer, $\mathrm{pH} 9 \cdot 0$.

One dimensional separation. Samples ranging in size from 0.5 to $1.0 \mu \mathrm{l}$ were absorbed onto cellulose acetate paper strips (Separaphore III*) measuring $2 \times 3 \mathrm{~mm}$. Somewhat longer strips were used if the sample volume allowed. The reference fluids, serum, plasma and testicular lymph were diluted so that the final protein concentration corresponded to that of rete testis fluid and tubular fluid. The strips containing the samples were placed on the surface of the $4.5 \%$ gel. An $8 \%$ acrylamide gel cap, cast in another casting stand, was pressed against the upper surface of the sample containing strips. Electrophoretic separation was provided by means of a pulsed constant power supply in which the initial pulse rate was 75 pulses/sec, increasing gradually up to 300 pulses/ sec. The voltage was $280 \mathrm{~V}$ and the capacitance was $1.0 \mu \mathrm{F}$. The total time for the run was $45 \mathrm{~min}$. The gels were fixed in $12 \%$ trichloroacetic acid, stained with a $0.2 \%$ solution of Coomassie blue and differentiated in $10 \%$ acetic acid.

Two dimensional separation. The two dimensional method provided an approach to the identification of the individual proteins present in the classical $\alpha$-, $\beta$ - and $\gamma$-globulin bands as established by Smithies (1959) on paper and starch.

The first stage was carried out in cellulose acetate electrophoresis (Gelman) using $0.05 \mathrm{M}$-tris-barbituric acid buffer, $\mathrm{pH} 8 \cdot 8$. Electrophoretic separation was carried out for 15 to $30 \mathrm{~min}$, using a pulsed constant power supply at $300 \mathrm{~V}$ and $0 \cdot 1 \mu \mathrm{F}$ at 300 pulses/sec. The cellulose acetate was then longitudinally cut into 3 -mm wide sections in the direction of electrophoretic separation. To identify the bands in the paper, one cellulose acetate strip was stained with Amido black. The thin strips were placed on the surface of the $4.5 \%$ gel and subjected to another electrophoretic separation and staining of the gels, using the techniques described above.

Microdensitometry. For semiquantitative estimation of the amounts of protein present in different parts of a gel, the stained gels were scanned with a Joyce GWB microdensitometer. A general description of the instrument is given by Altman (1971). The densitometer curve was quantified by extending the baseline from a protein-free region to that part containing the protein peaks. Perpendiculars were then drawn from the midpoint of valleys between adjacent 
peaks to the baseline. The peak areas were cut out and weighed. The areas under each peak were expressed as a percentage of the total area. No attempt was made to correct eventual differences in the staining intensity of different proteins.

\section{Protein determination}

Protein was determined by the colorimetric method of Lowry, Rosebrough, Farr \& Randall (1951) with the Folin-Ciocalteau phenol reagent. Crystalline serum albumin was used as the standard. The absorbencies were read with a Coleman Junior ${ }^{\circledast}$ II spectrophotometer at $750 \mathrm{~nm}$.

Histochemical demonstration of enzyme activities in acrylamide gel

The enzyme activities of the electrophoretically separated proteins were studied on the gel, using histochemical methods. After the histochemical reaction was established, the bands visible on the gels were matched with the Coomassie blue-stained protein bands.

Acid phosphatase activity was detected according to the method of Allen \& Hunter (1960) with minor modifications. The gels were incubated in $0.1 \mathrm{M}$ acetate buffer $\left(\mathrm{pH} \mathrm{5.0)}\right.$ for $30 \mathrm{~min}$ at $21^{\circ} \mathrm{C}$ and transferred to an incubation solution composed of $0.1 \mathrm{M}$-acetate buffer ( $\mathrm{pH} \mathrm{5.0}$ ), $0.025 \mathrm{M}$-sodium $\alpha$-naphthyl acid phosphate (Dajac Laboratories, Philadelphia) and $1 \mathrm{mg}$ Fast blue BB (G. T. Gurr Ltd, London) $/ \mathrm{ml}$. After incubation at $37^{\circ} \mathrm{C}$ for $30 \mathrm{~min}$, the gels were stored in $10 \%$ acetic acid.

Esterase activity was demonstrated according to the method of Allen, Popp \& Moore (1965). The substrate solution consisted of $100 \mathrm{ml}$ of $0.1 \mathrm{M}$-phosphate buffer (pH 7.4), $4 \mathrm{ml}$ of a $1 \%$ acetone solution of $\alpha$-naphthyl acetate (BDH Laboratory Chemicals, Poole) and $100 \mathrm{mg}$ Fast blue RR (G. T. Gurr Ltd, London). The gels were first equilibrated in the buffer solution for $10 \mathrm{~min}$ and then transferred to the incubation solution. The incubation time was $15 \mathrm{~min}$ at $37^{\circ} \mathrm{C}$. The reaction was stopped with an acid:alcohol mixture consisting of $20 \mathrm{ml}$ of $95 \%$ ethyl alcohol and $80 \mathrm{ml}$ of $10 \%$ acetic acid. Eserine (E. Merck AG, Darmstadt) in a concentration of $10^{-3} \mathrm{M}$ was used in preincubation and incubation solutions to study the eserine sensitivity of the esterase activities.

\section{RESULTS}

Electrophoretic separation of rete testis fluid and seminiferous tubule fluid proteins

In ordinary cellulose acetate electrophoresis, a relatively strong band was constantly seen in the rete testis fluid between $\alpha_{1}$ - and $\alpha_{2}$-globulins. This seemed to be specific to rete testis fluid. Very little albumin was present and only traces of other serum proteins. The result was very similar to the pattern described by Johnson \& Setchell (1968). Tubule fluid was available in too small amounts to give an intense staining in cellulose acetate electrophoresis.

Acrylamide gel electrophoresis with semiquantitative estimations. In one-dimensional separations, the electrophoretic separation of the proteins of the tubule fluid revealed a total of twenty-three bands (Band 4, only occasional and weak). Nine bands were identical electrophoretically with serum proteins (Bands 1, 3, 


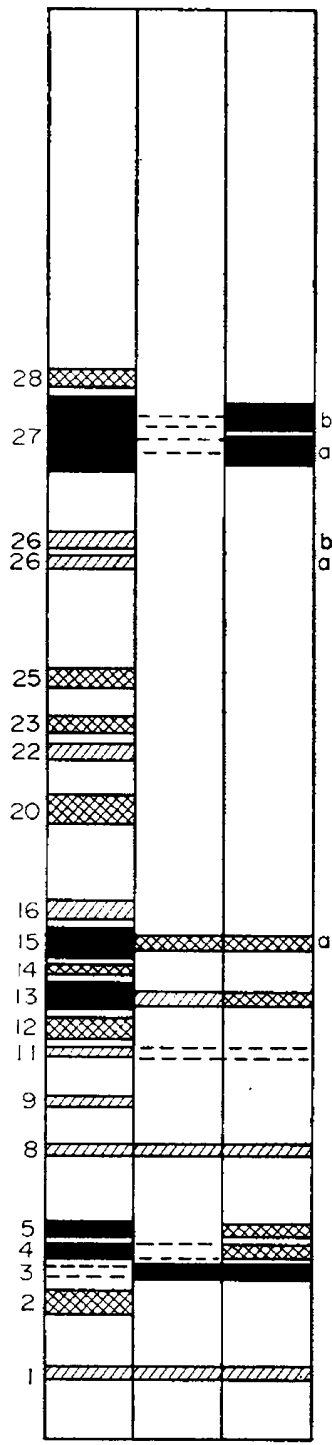

$S \quad T_{s} \quad R_{s}$

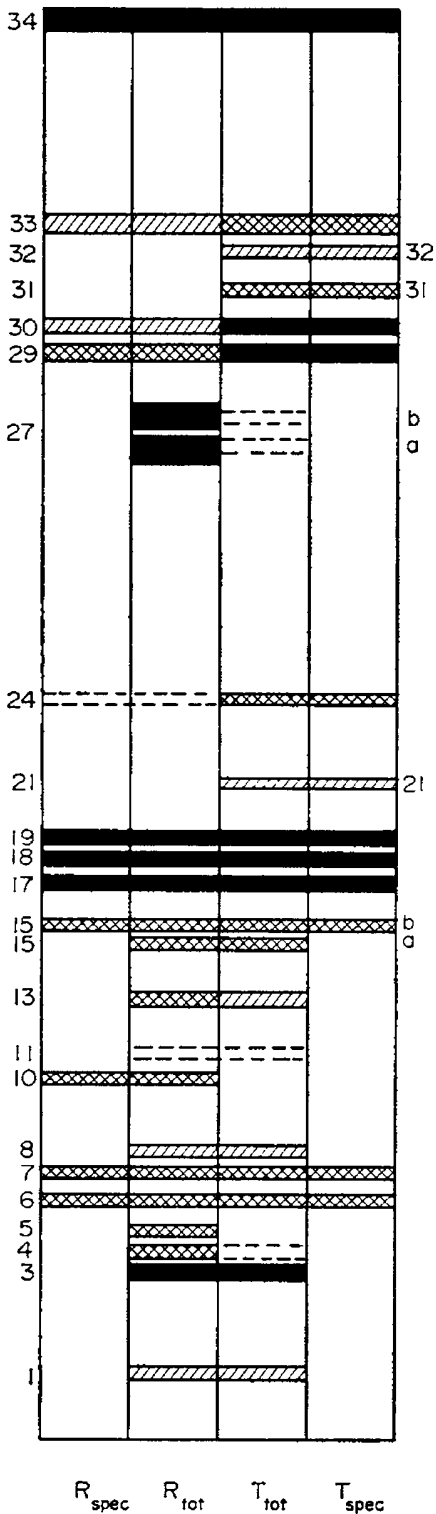

$R_{\text {spec }} R_{\text {tot }} T_{\text {tot }} T_{\text {spec }}$

TeXT-FIG. 1. Diagrammatic presentation of the protein bands seen in step gradient, acrylamide gel electrophoresis of rat body fluids and the numbering used in the text and other diagrams. $\mathrm{S}=$ serum; $\mathrm{T}_{\mathrm{s}}=$ serum protein bands seen in the seminiferous tubule fluid; $R_{s}=$ serum protein bands seen in the rete testis fluid; $\mathbf{R}_{\mathbf{s p e c}}=$ protein bands specific to the rete testis fluid (e.g. those not seen in serum); $R_{\text {tot }}=$ total pattern of the rete testis fluid; $T_{\text {tor }}=$ total protein band pattern of the seminiferous tubule fluid; $\mathrm{T}_{\mathrm{spec}}=$ bands specific to the tubule fluid (e.g. not seen in the serum). Very weak or inconstant bands are drawn with dotted lines. 
$4,8,11,13,15 a, 27 \mathrm{a}$ and $\mathrm{b})$ and all nine were relatively weakly stained (Textfig. 1). This was especially true of Band 27 (albumin), which was a strong, intense band both in serum and in rete testis fluid but, in tubule fluid, it was a very weakly stained doublet (27 $\mathrm{a}$ and $\mathrm{b}$ in Text-fig. 1 and Pl. 1, Fig. 1). Two distinct groups were typical of rete testis fluid and tubule fluid. One of them consisted of four bands in rete testis fluid and six bands in tubular fluid moving in front of the fastest moving albumin fraction of serum (Bands 29 to 34). These were thought to be equivalent to the small protein found in the ram rete testis fluid (Setchell, 1967). Another characteristic group of bands showed intermediate mobility, appearing as three thin but strong bands $(17,18,19)$. Surprisingly, there were some weak bands (two relatively weak and broad bands, nos 21 and 32, and a less constant one, no. 31) which were found in tubule fluid but not in rete testis fluid. The rest of the non-serum protein bands were weaker and mainly slow moving. All the protein bands seen in rete testis fluid or tubular fluid but not in serum will here be called 'specific bands'. The protein pattern of the fluid collected from the distended seminiferous tubules due to efferent duct ligation was identical to that obtained by puncturing normal, nondistended tubules.

Rete testis fluid proteins appeared to be a mixture of the proteins from the seminiferous tubule fluid and some serum proteins (Text-fig. 1). Only one band seemed to be specific to rete testis fluid (Band 10), but this did not appear constantly. All the other rete testis fluid bands were visible either in the tubule fluid or in serum. All the serum bands visible in the tubule fluid were also seen in rete testis fluid, but Bands $27 \mathrm{a}$ and b especially were consistently stronger in the latter. Serum band no. 5 was seen in rete testis fluid, though not in tubule fluid. All the reference fluids, e.g. serum, plasma and intratesticular lymph, proved to have a highly similar pattern of protein bands except for the distinct fraction of fibrinogen in plasma and the slight predominance of fast moving proteins in the lymph. A total of twenty-one separate bands were identifiable in the serum (Text-fig. 1), although some of them (Bands 1, 3, 8, 14) were not always seen.

The relative amounts of different protein fractions of both fluids were estimated using microdensitometric curves, examples of which are given in $\mathrm{Pl}$. 2, Fig. $3 \mathrm{a}$ and b. Albumin (Band 27), which in rat serum represents $41 \%$, represents about $14 \%$ of the total protein in the rete testis fluid and only about $3 \%$ in tubular fluid. A surprising number of the fractions consisted of proteins of high molecular weight migrating primarily in the $4 \frac{1}{2}$ and $6 \%$ layers of acrylamide. In both fluids, this fraction (from Bands 1 to 15) consisted of about $50 \%$ of the total protein. Consequently, the albumin-globulin ratio, which in serum is about $0.7 \%$, is only 0.3 and 0.2 in rete testis fluid and tubule fluid, respectively (Table 1).

The amount and mobility of specific proteins. All the fast moving protein bands in acrylamide electrophoresis were specific to rete testis fluid and tubular fluid. Their relative amounts were 5 and $9 \%$, respectively. Another distinct group of proteins was the triple band (Bands 17, 18,19), which contained 6 and $11 \%$ of the total of protein fractions. There were still some weak specific bands (in rete testis fluid, 24,15b, 10, 7, and in tubular fluid, 21, 15b, 7), the relative amounts 


\section{PLATE 1}

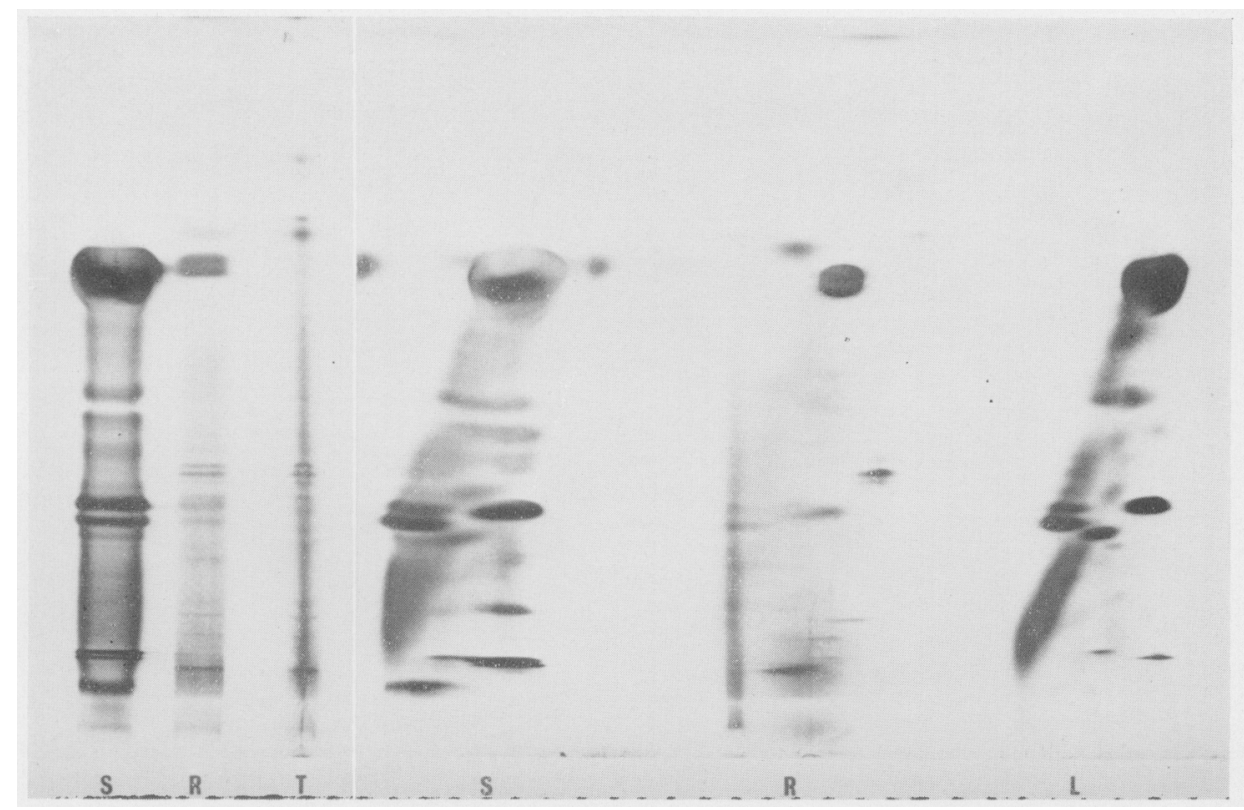

FIG. 1. Unidimensional (left) and two-dimensional (right) electrophoresis. Significance of letters in this and all following Plate figures: $\mathrm{S}=$ serum; $\mathrm{R}=$ rete testis fluid; $\mathrm{T}=$ seminiferous tubule fluid; $\mathrm{L}=$ intratesticular lymph.
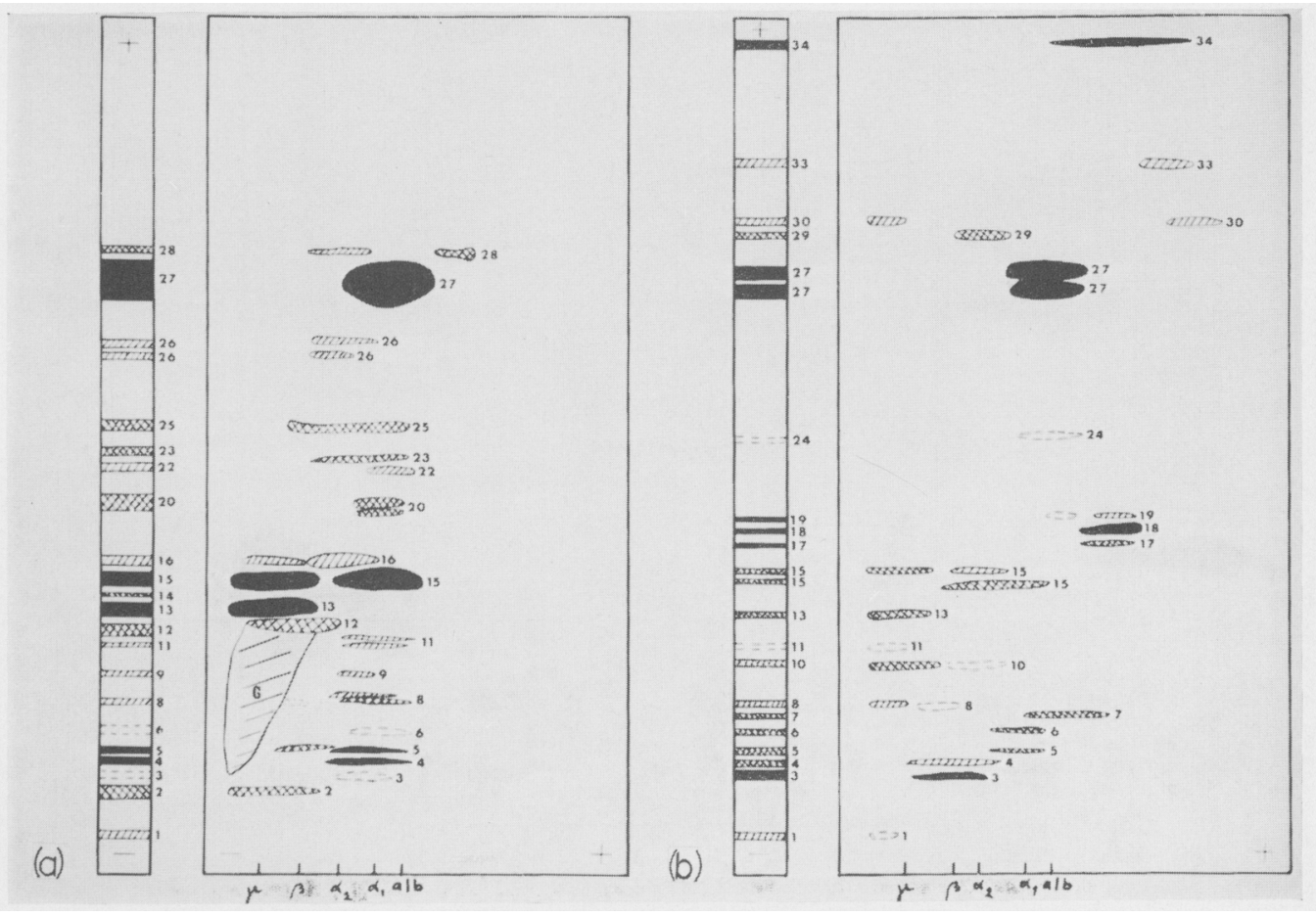

FIG. 2. Diagram of the electrophoretic separations in two dimensions. (a) Serum. (b) Rete testis fluid. 
PLATE 2

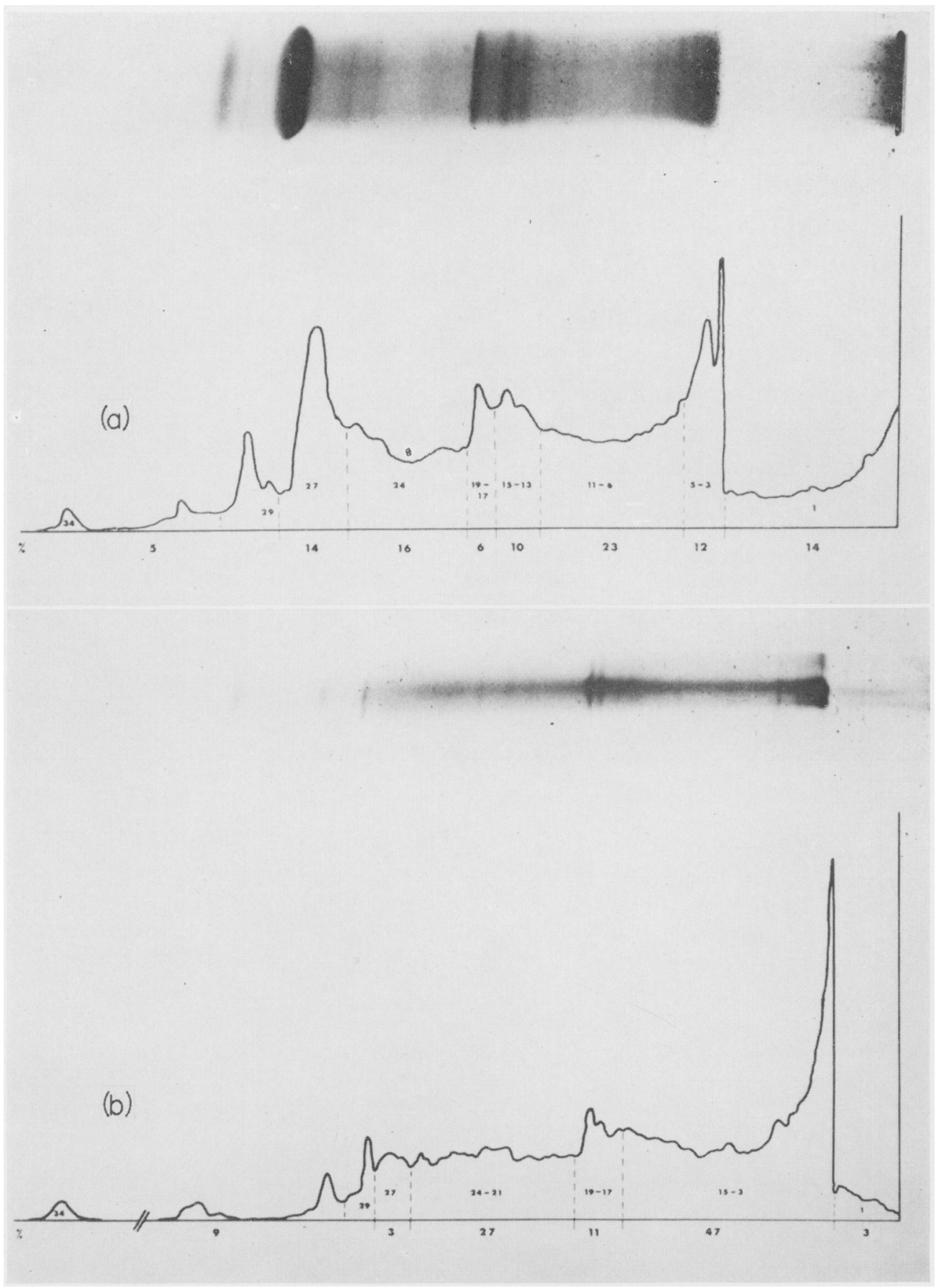

FIG. 3. Microdensitometry of rat rete testis fluid proteins (a) and seminiferous tubule fluid proteins (b) after electrophoretic separation on polyacrylamide gel. The scanned gels are at the upper margin of the figures and the relative amount of each fraction ( $\%)$ is marked under the baseline. 
PLATE 3

(a)

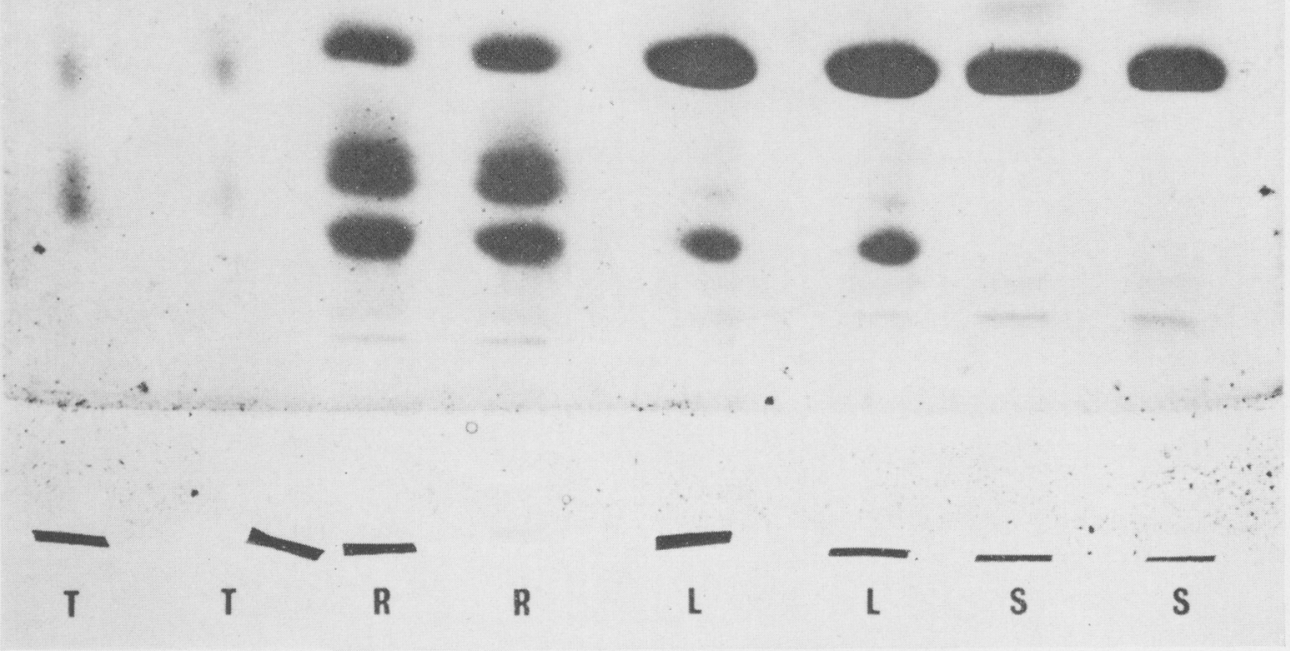

(b)

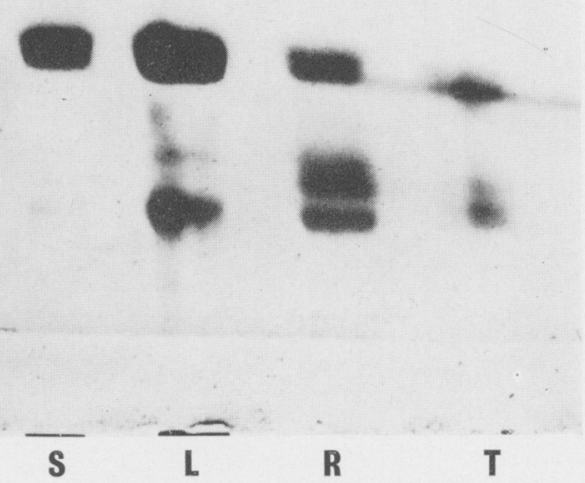

Fic. 4. Pattern of esterase activity with $\alpha$-naphthyl acetate as substrate after electrophoretic separation of proteins in rat body fluids. (a) No inhibitor used. (b) Esterase activities of the same fluids after inhibition with $10^{-3}$ M-eserine. 
PLATE 4

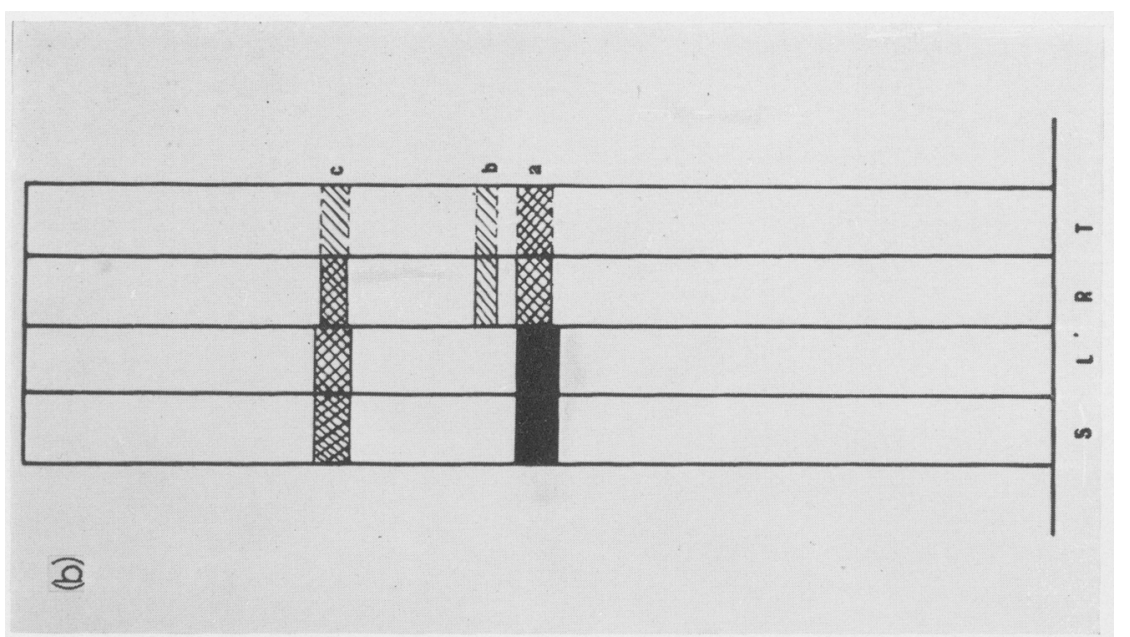

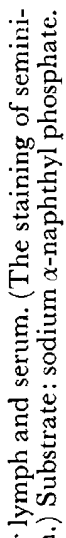

急

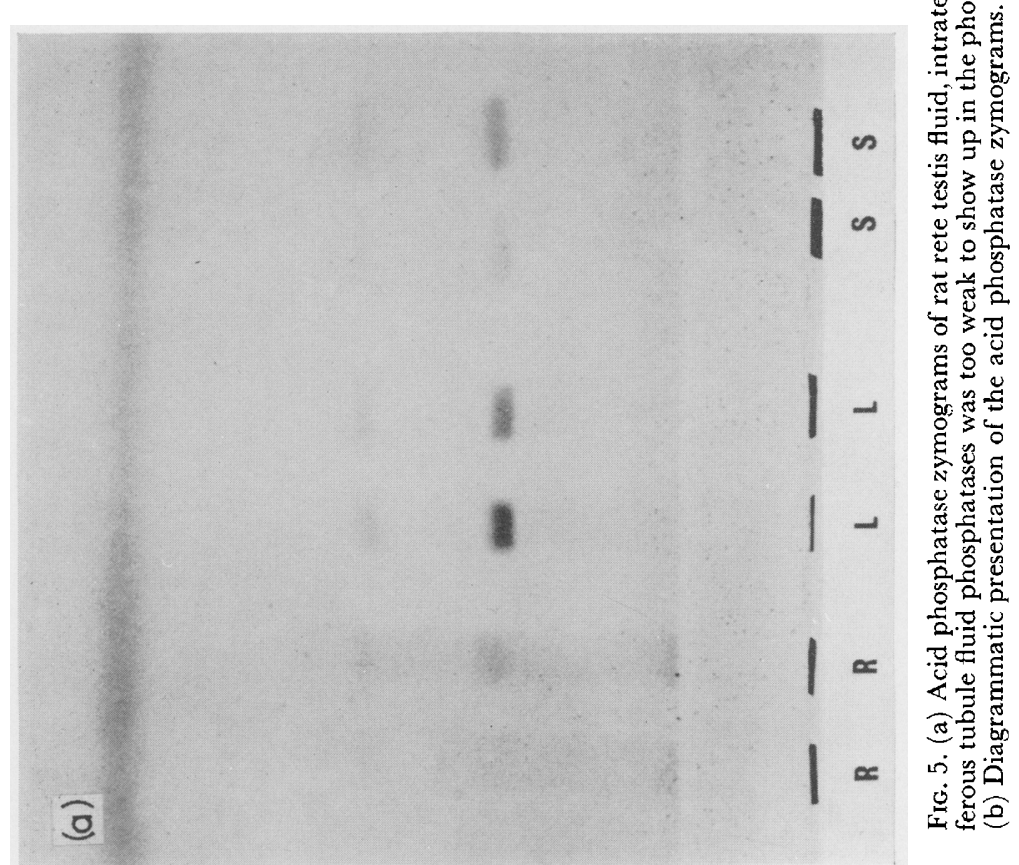


of which were estimated to be about $5 \%$ in both fluids. Thus, the specific bands consisted of $16 \%$ and $25 \%$ of the total protein content in rete testis fluid and in tubular fluid, respectively.

Two-dimensional electrophoresis. The two-dimensional separation of rete testis fluid gave more information on the nature of the specific protein bands identified after one-dimensional acrylamide gel electrophoresis. In two dimensions, the bulk of the specific protein, which in cellulose acetate moves between $\alpha_{1}$ and $\alpha_{2}$-globulins, was found to move fast (in Band 29) in acrylamide. Thus, it is worth noting that Band 29 , which, in acrylamide, moves as a 'light' protein, is not a prealbumin. Specific bands 17, 18 and 19, which had an intermediate mobility in acrylamide and which were constantly found both in rete testis fluid and tubular fluid, moved with prealbumins in cellulose acetate (Pl. 1, Fig. $2 a$ and $b$ ). Consequently, the specific proteins are largely prealbumins.

Table 1. Protein concentration and albumin-globulin ratio of rat serum, rete testis fluid and seminiferous tubule fluid and the relative amount of specific proteins of the last two fluids

\begin{tabular}{l|c|c|c}
\hline & $\begin{array}{c}\text { Rete testis } \\
\text { fuid }\end{array}$ & $\begin{array}{c}\text { Seminiferous } \\
\text { tubule fluid }\end{array}$ & Serum \\
\hline Mean protein content in $\mathrm{mg} / \mathrm{ml} \pm$ S.E. & $\mathbf{5 \cdot 7 \pm 0 \cdot 3}$ & N.D. & $63 \cdot 0 \pm 0 \cdot 8$ \\
Albumin-globulin ratio & $0 \cdot 3$ & $0 \cdot 2$ & $0 \cdot 7$ \\
Specific proteins (\% of total) & 16 & 25 & - \\
\hline
\end{tabular}

N.D. = not determined.

The prealbumin portion comprises about $9 \%$ of the total proteins in rete testis fluid and about $16 \%$ in tubular fluid, and more than half the total specific proteins.

The protein content of rete testis fuid. The total protein content measured from rete testis fluid was about $10 \%$ of that of serum (Table 1 ). The concentration of the specific proteins in rete testis fluid was about $1 \mathrm{mg} / \mathrm{ml}$, calculated from the microdensitometric curves. These values were slightly higher than those given by Setchell (1970), who used a long-term cannulation instead of short-term puncture of the rete testis.

Esterases and acid phosphatases of the testicular fluids

Esterases. The distribution of protein bands showing esterase activity in electrophoretically separated testicular fluid proteins is shown in Text-fig. 2. With $\alpha$-naphthyl acetate as substrate, four distinctly active zones were constantly found in serum. Two of these $(\mathrm{C}$ and $\mathrm{J})$ were not found in rete testis fluid or in tubular fluid. The esterase pattern of testicular lymph to some extent resembled that of rete testis fluid (Pl. 3, Fig. 4a). Only Zone I was resistant to eserine inhibition. This strong zone was also found in all the other fluids (Pl. 3, Fig. 4b). Zone B, which in serum was inhibited by eserine, was constantly found in lymph even after eserine inhibition. The esterases of rete testis fluid appeared in strongly stained zones. Except for Zone B, which probably originated from serum, all the zones were eserine-resistant (Text-fig. 2). Zone G, 
seen in both rete testis fluid and tubular fluid, was absent in serum and lymph. The very distinct and narrow Zone A was only found in rete testis fluid. In tubular fluid, Zone I was much weaker than in the other fluids, but just beneath it, there appeared an intense zone $(\mathrm{H})$. All the esterase zones in tubular fluid were resistant to eserine (Text-fig. 2).

It was remarkable that the zones did not always correspond to the individual

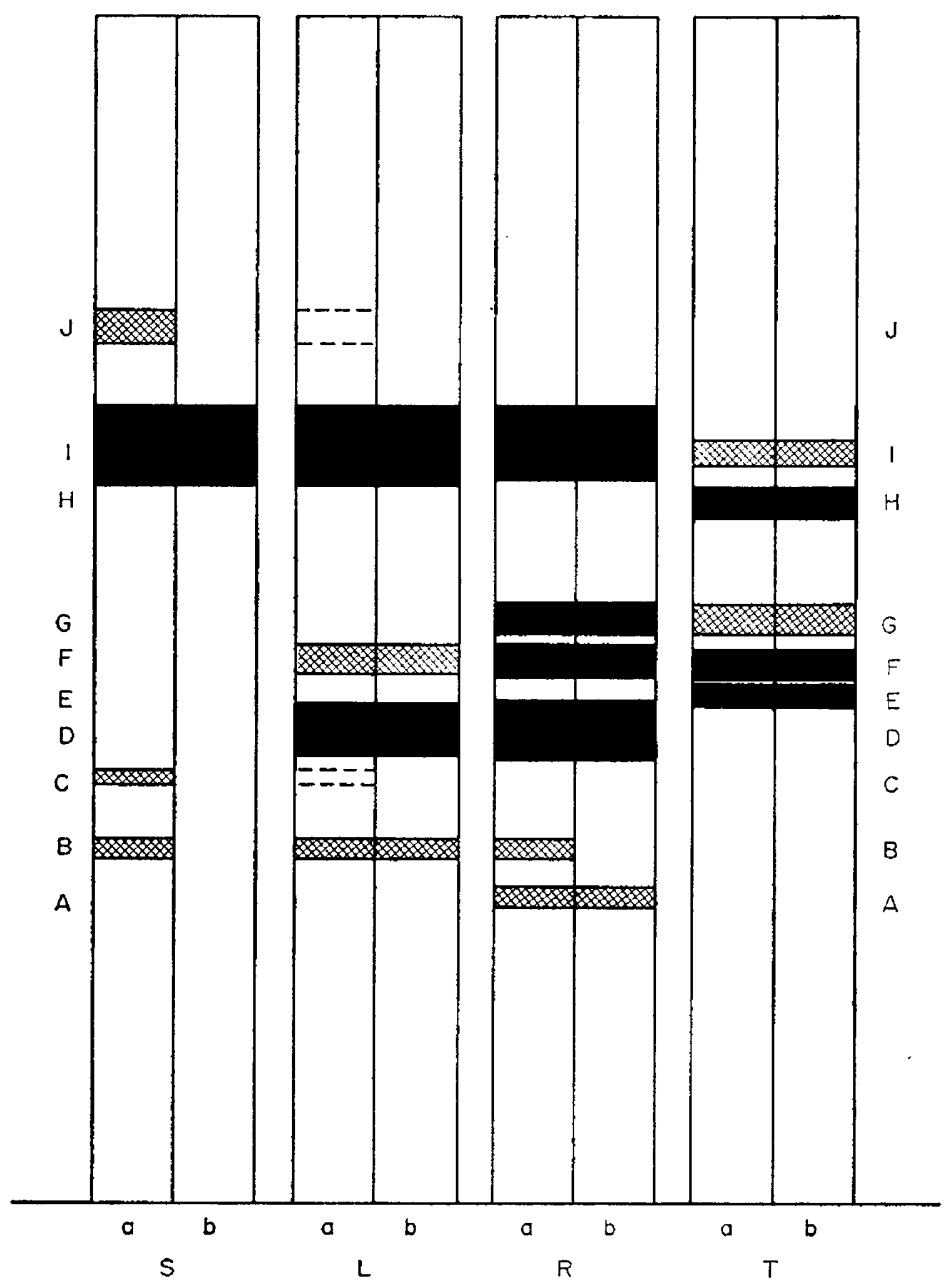

TEXT-FIG. 2. Diagrammatic presentation of the esterases of rat serum (S), intratesticular lymph (L), rete testis fluid $(R)$ and seminiferous tubule fluid $(T)$. The ' $a$ ' columns indicate the pattern of total activity and the ' $b$ ' columns show the eserine-resistant zones.

protein bands, and often the zone intensity was distributed over several bands. Zones A, B and C were located in protein fractions 6 to 11 (see Text-fig. 1). The strong Zone $\mathrm{D}$ was located in fraction 13 to 15 . In rete testis fluid and tubular fluid, Zones F and G appeared around the 'triple' fraction (Bands 17, 18, 19) and Zone $\mathrm{E}$ in tubular fluid just beneath these bands. In lymph, Zone $\mathrm{F}$ was very weak. The strong Zone I was located just beneath the albumin band 
(no. 27) and the weak $\mathrm{J}$ zone in serum and lymph was seen in the prealbumin fraction.

Acid phosphatases. Both rete testis fluid and seminiferous tubule fluid revealed a total of three zones with phosphatase activity in acrylamide gel. In tubular fluid, the zones were weaker and not as distinct as in rete testis fluid. One of these (Zone b) was present in both testicular fluids but not in serum or lymph (Pl. 4, Fig. 5a and b). Zones a and c, which stained intensely in serum and lymph, were attenuated in rete testis fluid and to some extent also in tubule fluid (PI. 4, Fig. 5b). Specific Zone b was located in the region of the 'triple' fraction (Bands 17, 18, 19) and Band a was in the fraction 13 to 15 . Zone $c$ had about the same mobility as albumin (Band 27).

\section{DISCUSSION}

The observations made here have important consequences for an understanding of the function of both the seminiferous tubules and rete testis. Using a step gradient, polyacrylamide gel system, it was possible to investigate the protein composition of seminiferous tubule fluid from samples ranging in size from 0.5 to $1.0 \mu \mathrm{l}$. Moreover, this system offered a high level of electrophoretic resolution of proteins of the testicular fluids compared with other methods. As polyacrylamide gel electrophoresis simultaneously exploits differences in molecular size and charge for the purpose of fractionation (Chrambach \& Rodhard, 1971), some information was also obtained about the molecular size of the different protein bands.

\section{Access of serum proteins into testicular fluids}

The seminiferous tubule fluid contained very small amounts of serum protein. Albumin was nearly absent and the bulk of the serum proteins was of high molecular weight. In contrast to the tubular fluid, rete testis fluid consisted of considerable amounts of serum protein, mainly albumin and slow-moving globulins. Due to these quantitative differences between the two fluids, the proportion of the specific proteins in seminiferous tubule fluid is relatively greater. This observation emphasizes the fact that rete testis fluid cannot be used as a representative of the composition of the secretion of the seminiferous tubules. The observations by Tuck et al. (1970) agree with this finding. They noted that the 'primary fluid' of the seminiferous tubules, i.e. the fluid which was secreted by the seminiferous tubules after they had been emptied of freeflow fluid by injection of oil, was rich in potassium, while the rete testis fluid was rich in sodium and chloride, and 'free-flow fluid', i.e. the fluid normally present in the seminiferous tubules, had an electrolyte composition which was intermediate between the other secretions. Various other observations, such as the greater permeability of the rete testis to dyes (Kormano, 1967) and the involvement of the rete testis before the rest of the organ in experimental allergic orchitis (Waksman, 1959), suggest that the rete testis is the weak point in the barrier system or may even be outside it.

In our study, 'free-flow' samples of seminiferous tubule fluid were analysed. Recently, Henning \& Young (1971) used the stopped-flow microperfusion 
technique to study the ionic composition of the tubular fluids. Their results suggest that in the primary fluid, there may be even less serum contamination than in the free-flow fluid. Due to the intermediate ionic composition of freeflow fluid, it has been postulated (Tuck et al., 1970) that rete testis fluid mixes with tubular fluid by reflux.

\section{Specific proteins and their origin}

The specific proteins seen in both fluids appeared in two distinct and easily identifiable groups. The greater proportion of the specific proteins in tubular fluid (about $1 / 4$ of the total protein) could be explained purely on the basis of quantitative differences in serum contamination between this fluid and rete testis fluid. The rete testis could also absorb specific constituents of the fluid (Leeson, 1962; Kormano et al., 1971) and at the same time it probably secretes a rete testis fluid that chemically resembles serum more than seminiferous tubule fluid in its ionic composition (Tuck et al., 1970). When the basic pattern of the specific proteins in rat seminiferous tubule fluid is compared with that of human seminiferous tubule fluid (Koskimies, Kormano \& Alfthan, 1973), they look remarkably similar. They both contain specific proteins moving quickly and at intermediate speed in acrylamide gel.

The results of the two-dimensional separations show that the bulk of the specific protein bands were prealbumins and that the specific protein fraction between $\alpha_{1}$ - and $\alpha_{2}$-globulins was mostly of low molecular weight. These 'light' proteins could be identical to the low molecular weight $(20,000$ to 30,000$)$ fractions found in sheep rete testis fluid by Setchell (1967).

The flow rate of rat rete testis fluid has been calculated to be about $20 \mu \mathrm{l} / \mathrm{hr} / \mathrm{g}$ from the weight gain of the testis after efferent duct ligation (Setchell, 1970). This value is slightly more than twice the rate in the ram, which is about 2 $\mathrm{ml} / \mathrm{hr} / 200 \mathrm{~g}$ testis (Voglmayr et al., 1966; Voglmayr, Scott, Setchell \& Waites, 1967). From this, it can be calculated that the total protein excretion in one rat testis is about $11 \mathrm{mg} / \mathrm{hr}$, with specific proteins accounting for about $2 \mathrm{mg}$. The fate of these specific proteins is still uncertain, but it is likely that most of them are resorbed in the head of the epididymis (Crabo, 1965), as we found only some of them in ductus deferens fluid (A.I. Koskimies, unpublished observations).

In addition to these specific proteins, one very remarkable group was the protein fraction of high molecular weight, which consisted of nearly half of the total protein in both fluids. In acrylamide gel, this fraction also seems to include the heavy $\alpha_{2}$-protein, which Johnson \& Setchell (1968) found in ram rete testis fluid.

They found that it gave a cross-reaction with ram serum $\alpha_{2}$-macroglobulin and thought that these proteins might be identical. It has been shown that $\alpha_{2}$-macroglobulin and its analogues are related to the stimulation of DNA synthesis (Berenblum, Burger \& Knyszynski, 1968) and during periods of rapid cell division, they are present at elevated blood levels (Heim, 1968). Besides the heavy $\alpha_{2}$-globulin, it is apparent that there are still considerable amounts of proteins of high molecular weight. On the other hand, it is known that much lipid is absorbed by the epithelium of the ductuli efferentes (Niemi \& Kormano, 
1965b) and that testicular spermatozoa can draw on their own lipid reserves (Scott, Voglmayr \& Setchell, 1967). The question of whether these lipids are associated with proteins needs further study.

\section{Enzyme activities of testicular fluids}

The esterase isoenzymes of seminiferous tubule fluid were all non-specific and resistant to $10^{-3} \mathrm{M}$-eserine. The rete testis fluid esterases contained one eserinesensitive isoenzyme, which was also found in serum. The other isoenzymes in rete testis fluid were identical with tubule fluid esterases. The acid phosphatase zones in seminiferous tubule fluid and in rete testis fluid were remarkably similar, both containing one non-serum band. The serum-like activity in tubular fluid and rete testis fluid was considerably attenuated compared with serum and lymph.

All the specific zones of these two enzymes with intermediate mobility were located in the 'triple' protein fraction of seminiferous tubule fluid and rete testis fluid. Histochemical studies show that Sertoli cells contain non-specific esterase activity which is resistant to various inhibitors (Niemi \& Kormano, 1965a). It is also known that acid phosphatase and lipid-containing particles are partially discharged with mature spermatozoa and partially phagocytosed by Sertoli cells (Niemi \& Kormano, 1965b). This is indirect evidence of the possibility that Sertoli cells elaborate most of these specific proteins and enzymes, which is not incompatible with the view that Sertoli cells are responsible for secretion of the tubule fluid (Setchell, 1969).

The present results are in agreement with the recent observations of Suominen \& Setchell (1972), who noticed that most of the rete testis fluid enzymes are not those contained by germinal cells. They also found that the activity of most enzymes per unit weight of protein was higher in the rete testis fluid than in blood plasma. Some of the specific enzyme bands could be related to residual body release, but, in recent studies on human seminiferous tubule fluid (Koskimies et al., 1973), we found that the specific protein bands were present even in fluid taken from severely damaged tubules. The tubules consisted mostly of Sertoli cells, the rest of the spermatogenic epithelium having degenerated.

\section{ACKNOWLEDGMENTS}

We are grateful to Professor R. L. Hunter, University of California, Davis, California, U.S.A., for his great help and advice in setting up the electrophoretic technique used in this study. This study has been supported by a grant from the Sigrid Juselius Foundation, Helsinki, Finland.

\section{REFERENCES}

ALLEN, J. M. \& Hunter R. L. (1960) A histochemical study of enzymes in the epididymis of normal, castrated and hormone replaced castrated mice separated by zone electrophoresis in starch gels. F. Histochem. Cytochem. 8, 50 .

Allen, R. G., Popp, R. A. \& Moore, D. J. (1965) Separation and relative quantitation of mouse plasma esterases with disc electrophoresis. 7. Histochem. Cytochem. 13, 259.

Altman, F. P. (1971) The use of a recording microdensitometer for the quantitative measurement of enzyme activities inside tissue sections. Histochemie, 27, 125. 
Berenblum, I., Burger, M. \& Knyszynski, A. (1968) Regeneration of bone marrow cells and thymus induced by ${ }^{19} \mathrm{~S} \alpha_{2}$-globulin in irradiated mice. Nature, Lond. $217,857$.

Chrambach, A. \& Rodhard, D. (1971) Polyacrylamide gel electrophoresis. Science, N.r. 172, 440.

CRABo, B. (1965) Studies on the composition of epididymal content in bulls and boars. Acta vet. scand. 6, Suppl. 5, 1 .

ERÄNKö, O., HunTER, R. L. \& Koskimies, A. I. (1973) Two-dimensional electrophoresis of rat serum esterases in cellulose acetate and acrylamide gradient gel. Experientia (In press).

HeIm, W. G. (1968) Relation between rat slow $\alpha_{2}$-globulin and $\alpha_{2}$-macroglobulin of other mammals. Nature, Lond. 217, 857.

Henning, R. D. \& Young, J. A. (1971) Electrolyte transport in the seminiferous tubules of the rat studied by the stopped-flow microperfusion technique. Experientia, 27, 1037.

Hugciss, C. \& Moulton, S. H. (1948) Esterases of testis and other tissues. F. exp. Med. 88, 169.

Johnson, M. H. \& Setchell, B. P. (1968) Protein and immunoglobulin content of rete testis fluid of rams. 7. Reprod. Fert. 17, 403.

Kormano, M. (1967) Dye permeability and alkaline phosphatase activity of testicular capillaries in the postnatal rat. Histochemie, 9, 327.

Kormano, M., Koskimies, A. I. \& Hunter, R. L. (1971) The presence of specific proteins, in the absence of many serum proteins, in the rat seminiferous tubule fluid. Experientia, 27, 1461.

Koskimies, A. I., Kormano, M. \& Alfthan, O. (1973) Proteins of the seminiferous tubule fluid in man - evidence for a blood-testis barrier. F. Reprod. Fert. 32, 79.

Koskimies, A. I., Kormano, M. \& LAhti, A. (1971) A difference in the immunoglobulin content of seminiferous tubule fluid and rete testis fluid of the rat. F. Reprod. Fert. 27, 463.

LeEson, T. S. (1962) Electron microscopy of the rete testis of the rat. Anat. Rec. $144,57$.

LeVine, N. \& Marsh, D. J. (1971) Micropuncture studies of the electrochemical aspects of fluid and electrolyte transport in individual seminiferous tubules, the epididymis and the vas deferens in rats. F. Physiol., Lond. 213, 557.

Lowry, O. H., Rosebrough, N. J., Farr, A. L. \& Randall, R. J. (1951) Protein measurement with the Folin phenol reagent. $\mathcal{F}$. biol. Chem. 193, 265.

Nachlas, M. M. \& Seligman, A. M. (1949) Evidence for the specificity of esterase and lipase by the use of three chromogenic substrates. F. biol. Chem. 181, 343.

Niemi, M. \& Kormano, M. (1965a) Histochemical demonstration of a G-esterase activity in the seminiferous tubules of the rat testis. 7. Reprod. Fert. 10, 49.

Niemi, M. \& Kormano, M. (1965b) Cyclical changes in and significance of lipids and acid phosphatase activity in the seminiferous tubules of the rat testis. Anat. Rec. 151, 159.

ORTEC AN32 (1970) Techniques for high resolution electrophoresis. Ortec, Inc., Oak Ridge, Tennessee.

Pósalaky, Z., Szabó, D., BÁcsi, E. \& ÓköRös, J. (1968) Hydrolytic enzymes during spermatogenesis in rat. An electron microscopic and histochemical study. F. Histochem. Cytochem. 16, 249.

Scott, T. W., Voglmayr, J. K. \& Setchell, B. P. (1967) Lipid composition and metabolism in testicular and ejaculated ram spermatozoa. Biochem. F. 102, 456.

Setcheld, B. P. (1967) The blood-testicular fluid barrier in sheep. f. Physiol., Lond. 189, 63p.

SETChell, B. P. (1969) Do Sertoli cells secrete the rete testis fluid? F. Reprod. Fert. 19, 391.

Setchell, B. P. (1970) Testicular fluids. In: The Testis, Vol. I, p. 101. Eds. A. D. Johnson, W. R. Gomes and N. L. VanDemark. Academic Press, New York.

SMIthIEs, O. (1959) Zone electrophoresis in starch gels and its application to studies of serum proteins. Adv. Protein Chem. 14, 65.

Suominen, J. \& Setchell, B. P. (1972) Enzymes and trypsin inhibitor in the rete testis fluid of rams and boars. F. Reprod. Fert. 30, 235.

Tuck, R. R., Setchell, B. P., Waites, G. M. H. \& Young, J. A. (1970) The composition of fluid collected by micropuncture and catheterization from the seminiferous tubules and rete testis of rats. Pfligers Arch. ges. Physiol. 318, 225.

Voglmayr, J. K., Scotr, T. W., Setchell, B. P. \& Waites, G. M. H. (1967) Metabolism of testicular spermatozoa and characteristics of testicular fluid collected from conscious rams. F. Reprod. Fert. $14,87$.

Voglmayr, J. K., Waites, G. M. H. \& Setchell, B. P. (1966) Studies on spermatozoa and fluid collected directly from the testis of the conscious ram. Nature, Lond. 210, 861.

Waksman, B. H. (1959) A histologic study of the autoallergic testis lesion in the guinea pig. F. exp. Med. $109,311$. 